\title{
Kamu Kurumlarında İş Sağlığı ve Güvenliği Kanunu'nun İşveren, İşveren Temsilcisi veya Çalışan Temsilcileri Tarafından Uygulanmasının Değerlendirilmesi
}

\author{
Şenol Yavuz ${ }^{1 *}$, Berna Gür ${ }^{2}$ \\ ${ }^{1 *}$ Hitit Üniversitesi, Osmancık Ömer Derindere Meslek Yüksekokulu, Mülkiyet Koruma ve Güvenlik Bölümü, Çorum, Türkiye, (ORCID: 0000-0001-6261-9296), \\ senolyavuz@hitit.edu.tr. \\ ${ }^{2}$ Hitit Üniversitesi, Teknik Bilimler Meslek Yüksekokulu, Mülkiyet Koruma ve Güvenlik Bölümü, Çorum, Türkiye, (ORCID: 0000-0002-0674-4612), \\ bernagur@hitit.edu.tr
}

(İlk Geliş Tarihi 21 May 2021 ve Kabul Tarihi 5 Ağustos 2021)

(DOI: 10.31590 /ejosat.940303)

ATIF/REFERENCE: Yavuz, Ş. \& Gür, B. (2021). Kamu Kurumlarında İş Sağlı̆̆ ve Güvenliği Kanunu'nun İşveren, İşveren Temsilcisi veya Çalışan Temsilcileri Tarafından Uygulanmasının Değerlendirilmesi. Avrupa Bilim ve Teknoloji Dergisi, (25), 650-656.

\section{$\ddot{O} \mathbf{z}$}

Türkiye'de İSG Kanun kapsamında az tehlikeli sınıfta yer alan iş kollarından biri de ofis ortamlarının çoğunlukta olduğu üniversite fakülte ve MYO'larıdır. Üniversitelerde akademik ve idari personeller görev yapmaktadır. Üniversitelerin genellikle az tehlikeli sınıfta yer alması, iş kazası ve meslek hastalıkları istatistiklerinin az olması gibi nedenlerden İSG ile ilgili çalışmalar tam anlamıyla uygulanmamaktadır. Çalışmada Hitit Üniversitesinde fakülte ve MYO'larda işveren, işveren temsilcisi ve çalışan temsilcisi olarak görev yapanlar tarafından İSG Kanunu'nun uygulamasııın değerlendirilmesi amaçlanmaktadır. Çalışmanın örneklem grubunda yer alan kişi sayısı az olduğundan çalışmanın yöntemi nitel veri toplama araçlarından biri olan odak grup görüşmesi olarak belirlenmiştir. Odak grup görüşmesinde sorulacak sorular belirlenirken fakülte ve MYO'larda gözlemlenen İSG çalışma ve uygulamaları dikkate alınmıştır. Verilen cevaplar değerlendirildiğinde işveren, işveren temsilcisi ve çalışan temsilcilerinin İSG Kanunu'nundan ve kendi yükümlülüklerinden haberdar oldukları ancak İSG çalışmalarının tam anlamıyla yapılmadı̆̆ı, yapılan çalışmalara hâkim olunmadı̆̆ı ve İSG sürecinin takibinin yapılmadığı tespit edilmiştir.

Anahtar Kelimeler: Hitit Üniversitesi, İşveren/işveren vekili, İş sağlığı ve Güvenliği, Odak Görüşmesi, Çorum.

\section{Evaluation of the Implementation of the Occupational Health and Safety Law in Public Institutions by Employer, Employer Representative or Employee Representatives}

\begin{abstract}
One of the business lines in the less dangerous class in Turkey under the OHS Law is university faculties and vocational colleges where office environments are predominant. Academic and administrative staff work at universities. Studies on OHS are not fully implemented due to reasons such as the fact that universities are generally in the less dangerous class and the statistics of occupational accidents and occupational diseases are low. In the study, it is aimed to evaluate the implementation of the OHS Law by those who work as employer, employer representative and employee representative in faculties and vocational schools in Hitit University. Since the number of people in the sample group of the study is low, the method of the study was determined as the focus group interview, which is one of the qualitative data collection tools. While determining the questions to be asked in the focus group meeting, OHS studies and practices observed in faculties and vocational colleges were taken into consideration. When the answers given were evaluated, it was determined that the employer, employer representative and employee representatives were aware of the OHS law and their own obligations, but OHS studies were not fully carried out, the work was not mastered and the OHS process was not followed.
\end{abstract}

Keywords: Hitit University, Employer / Employer Representative, Occupational Health and Safety, Focus Meeting, Çorum.

\footnotetext{
*Sorumlu Yazar: senolyavuz@,hitit.edu.tr
} 


\section{Giriş}

İş sağlığı ve güvenliğinin düşünce olarak gelişme amacı; insanlığın oluşumundan başlayıp hayatın her evresinde güvenli olarak beslenme, barınma ve çalışma imkânının sağlanması ile ortaya çıkması sonucu gelişim göstermektedir. Çeşitli faaliyetlerde bulunulması sırada istenmeyen durumlardan kaçınmak üzere yapılan eylemlere iş sağlı̆̆ ve güvenliği denilmektedir(Terzioğlu \& Aksungur, 2019). İş sağlığının gelişimini sağlayan ana faktör sağlık alanındaki gelişmeler ve çalışma ortamı sırasında çalışanlarda tespit edilen hastalıklar olmuştur. Sanayileşme ile birlikte iş faktörü kaynaklı hastalıklar görülmeye başlanmıştır (Aktan \& Işık, 2007). İş sağlı̆̆ı ve iş güvenliği kavramları uygulamada biribirinden ayrılmaktadır. İş Sağlığı, sağlık standartlarına uygun olarak çalışanlara sağlıklı ortam ve çevre sağlanması iken iş güvenliği ise çalışanların vucüt bütünlüğü bozacak, yaşamsal olaylarını etkileyecek işyeri ortamındaki tehlike ve risklerin belirleyerek çalışma ortamın güvenliğinin sağlanmasıdır (Hekimler, 2012). Çalışma ortamındaki tehlike ve risklerin tespit edilmesinde, iş kazaları meslek hastalıklarının önlenmesinde iş sağlığ 1 ve iş güvenliğinin beraber uygulanması ve bu amaç doğrulusunda kullanılacak araç ve gereçlerin iş hukuku ile teminat altına alınır (Bayram, 2005; Çakan \& Yavuz, 2020).

Günümüzde iş sağlığı ve güvenliği, çalışanların sosyal, bedensel ve ruhsal yönden koşullarının tam iyilik halinin gösterilmesidir. İyilik halinin sürdürülmesi, işveren tarafindan uygulanma hedefi olması, çalışanların benimsemesi ile işyerinde iş kazaları ve meslek hastalıklarına karşı koruyucu proaktif yaklaşımlar kazanılmış olur (Çiçek \&Öçal, 2016; Kabakçı, 2009).

Uluslararası kuruluşların iş sağlığı ve güvenliği ile ilgili verdiği öneriler, yaptığı konferanslar, ülkelerin bu öneriler doğrultusunda yaptığı çalışmalar ile gelişmesi ve uygulanması daha kolay olmaktadır. Bu kuruluşlar içerisinde \%80 oranı ile en fazla rolü Uluslararası Çalışma Örgütü (ILO) üstlenmektedir. Uluslararası Çalışma Örgütü (ILO), çalışan yaşı, işyeri teftişi, işyeri hekimliği, güvenlik ve radyasyondan korunma, ortam ölçümleri konularda antlaşmaların yapılmasında rol almıştır (Aktan \& Iş1k, 2007; Şen, 2015).

Batılı ülkelerin aksine Türkiye İş sağlığı ve güvenliğinin hukuki gelişimi daha geç olmuştur. Spesifik bir alana sahip olmadığından İş Kanunun, Borçlar Kanunu'nun ve anayasanın içerisinde yer alarak uygulanmasına çalışılırken 2012 yılında çıkarılan 6331 sayılı İş Sağlığ ve Güvenliği Kanunu ile kendine özgü bir kanun ile uygulama alanı bulmuştur (Süzek, 2012; Aytekin,2012).

İş sağlığı ve güvenliği ile ilgili kurallar ve esaslar, ulusal mevzuatta anayasa ile güvence altına alınarak çeşitli kanun ve yönetmelikler ile uygulanması sağlanmaktadır. İş sağlığı ve güvenliğinin uygulanmasını sağlayan başlıca kanun ve yönetmelikler şunlardır (Terzioğlu \& Aksungur, 2019; Süzek, 2012);

1- Anayasa,

2- 6098 Sayılı Borçlar Kanunu,

3- Güncel 4857 Sayılı İş Kanunu,

4- 6331 sayılı İş Sağlı̆̆ı ve Güvenliği Kanunu,

5- İş sağlığı ve Güvenliği ile ilgili Yönetmelikler, -Risk Değerlendirmesi Yönetmeliği,

-İş Sağlıği ve Güvenliği Hizmetleri Yönetmeliği, -İşyerlerinde İşin Durdurulması İle İlgili Yönetmelik,

e-ISSN: 2148-2683
-Ekranlı Araçlarla Çalışmalarda Sağlık ve Güvenlik

Önlemleri Hakkında Yönetmelik,

-İşyerlerinde İşin Durdurulmasına Dair Yönetmelik,

30 Haziran 2012 yılında resmî gazete yayınlanarak yürürlüğe giren 6331 sayılı İş Sağlığı ve Güvenliği Kanunu'na göre iş kazası şu şekilde ifade edilmektedir: "Çalışan sigortalının işyerinde ve işin yürütümü nedeniyle meydana gelen, ölüme sebebiyet veren veya vucüt bütünlüğ̈̈nü ruhen ya da bedenen özre uğratan olaydır" (6331 3/g). İş kazası, 6331 sayılı yasadan daha fazla 5510 sayılı Sosyal Sigortalar ve Genel Sağlık Sigortası Kanunu'n 13.maddesinde daha ayrıntılı ifade edilerek iş kazalarının detayları vurgulanmıştır (Cengiz, 2018).

İş kazası, meslek hastalığı ile beraber literatürde "mesleki risk" olarak gruplandırılarak ilk defa 19.yy in ikinci yarısında ifade edilmiş ve gelişmeye başlamış bir kavramdır (Güzel, Okur \& Caniklioğlu, 2016). Teknoloji ile birlikte yeni yöntemler, makineler ve kullanılan maddelerden kaynaklı çeşitli iş kazaları ve meslek hastalıkları farkedilmese dahi sayısı yükselmeye başlamıştır. Gelişen süreçte, ilk olarak 1884 de iş kazası sigortası ve meslek hastalığı sigortası Almanya'da tanımlanarak çalışanların sosyal güvenlik yönünden korunması, güvence alınması yönünde çalışmalar yapılmaya başlanmıştır (Tuncay \& Ekmekçi, 2016; Yılmaz, 2017).

1897 yılında Birleşik Krallıkta İş Tazminatı Kanunu kabul edilerek kişisel olarak kayıp yaşayan çalışanların hakları korunmaya çalışılmış, dünya da ilk defa uygulanan ikinci iş kazası sigortası olması açısından kronolojik olarak tarihteki yerini almıştır. Bu kanuna göre, çalışan kazaya maruz kalması, iki hafta olarak iş kaybı yaşaması veya ölmesi halinde işverenin tazminat ödemesi gerektiği hükümü yer almaktadır (Yılmaz, 2017; Fabian Society, 1901).

İş kazası ve meslek hastalığı ile ilgili olarak çalışanların korunması ve güvence altına alınması tarihsel bir süreç içerisinde yapılan düzenlemeler ile günümüzde Avrupa da ve Türkiye de son halini alarak uygulanmaya çalışılmaktadır. Zaman içerisinde eksik kalan ve ilave edilmesi gereken hususlar yönetmelikler ile düzeltilmeye çalışılmaktadır. Ülkemizde 5510 Sayılı Sosyal Sigortalar ve Genel Sağlık Sigortası (SSGSSK) ile uygulanmaya çalışılmaktadır. 5510 sayılı yasanın 13. Maddesi iş kazaları, 14. Maddesi ise meslek hastalıklarıyla ilgili hükümler ile çalışanları güvence altına almaya çalışmaktadır (Yılmaz, 2017). 5510 sayılı yasaya göre iş kazası;

“a) Sigortalının işyerinde bulunduğu sırada,

b) Işveren tarafindan yürütülmekte olan iş nedeniyle sigortalı kendi adına ve hesabına bağımsız çalışıorsa yürütmekte olduğu iş nedeniyle,

c) Bir işverene bağll olarak çalışan sigortalının, görevli olarak işyeri dışında başka bir yere gönderilmesi nedeniyle asıl işini yapmaksızın geçen zamanlarda,

d) Bu Kanunun 4'üncü maddesinin birinci fikrasının (a) bendi kapsamındaki emziren kadın sigortalının, iş mevzuatı gereğince çocuğuna süt vermek için ayrılan zamanlarda,

e) Sigortalıların, işverence sağlanan bir taşıtla işin yapıldı̆̆ yere gidiş gelişi sırasinda, meydana gelen ve sigortaliyı hemen veya sonradan bedenen ya da ruhen engelli hâle getiren olay', olarak ifade edilmektedir (Yılmaz, 2017; Güzel, Okur \& Caniklioğlu, 2016). 


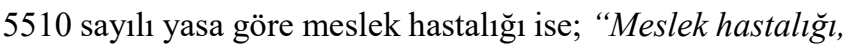
sigortalının çalıştığl veya yaptı̆̆ tekrarlanan bir sebeple veya işin yürütüm şartları yüzünden ŭgradı̆̆ geçici veya sürekli hastalı, bedensel veya ruhsal özürlülük halleridir" diye tanımlanmaktadır (SSGSSK, 2006; Ilıman, 2015).

İş kazalarının ve meslek hastalıklarının önlenmesi, devlet, işveren ve çalışan oluşan üçlü yapının görevlerini yerine getirmesi, denetimlerin yapılması ve yasalar ile çalışanın güvence altına alınması ile mümkün olmaktadır (Ilıman, 2015).

İşverenin başlıca görevleri şunlardır;

$\checkmark$ İşveren, 6331, 5510 ve 4857 sayılı kanunlardaki görev, sorumluluk ve yaptırımlarına hâkim olmalı (Terzioğlu \& Aksungur, 2019),

$\checkmark$ Çalışan sayısı elliyi geçiyor ve işin süresi altı aydan fazla ise işyerinde bir iş sağlığı ve güvenliği kurulu kurmalı, kurulun çalışmasını ve belirli aralıklardaki toplantılarının yapılmasını sağlamalı (Boz Eravcı, 2019),

$\checkmark$ Çalışanlarına ilk işe girişte, iş değişikliğinde, iş kazası ve meslek hastalığ 1 geçirdikten sonra işbaşı yaparken ve belli sürelerde verilmesi gereken iş sağlığ 1 ve güvenliği eğitimlerini vermeli, iş alakalı yeni proses, yeni makine alımında 0 iş ile alakalı tehlike ve risklere karşı çalışanlarını eğitimelidir (Kökten \& Avinç,2014; Kurt \& 2012),

$\checkmark$ İş kazalarını ve meslek hastalıklarını resmi üç iş günü içerisinde bildirerek düzenleyici önleyici faaliyetlerde bulunması gerekir,

$\checkmark$ İşyerinde iş sağlığı kültürünün oluşmasını ve İSG nin bir yaşam biçimi olarak çalışanlarına kazandırması gerekir,

$\checkmark$ Çalışanlarının iş sağlığı ve güvenliğine uyumunu ölçen performans değerlendirmesi yapmalı (Üngören \& Koç,2015),

$\checkmark$ İşin yürütümü sırasında çalışanlarının maruz kalacağı tehlike ve risklere karşı, çalışanlarının güvenliğini sağlamak için risk değerlendirmesi yapmalıdır (Akpınar\& Çakmakkaya, 2014),

$\checkmark$ İşveren, İş sağlığı ve güvenliği hizmetlerini sağlamak üzere işyeri hekimi ve iş güvenliği uzmanı görevlendirmelidir (Etöz \& Tulga, 2015).

$\checkmark$ Çalışanlara iş ile alakalı gerekli araçlar ve kişisel koruyucu donanmimları temin etmeli,

$\checkmark$ Acil durumlara karşı gerekli önlemleri almalı, tatbitat yapmalı ve acil durum ekiplerini oluşturmalıdır.

$\checkmark$ Çalışanların katılımının sağlandığı bir iş sağlığı ve güvenliği sistemi sağlamalıdır (Erol, 2015).

İşverenin görev ve yükümlülüklerinin yanısıra çalışanların da yapması gereken görevleri ise şunlardır (Erol, 2015);

$\checkmark$ İşyerinde kullandığı araç ve gerçleri kullanırken dikkat etmeli,

$\checkmark$ Makine ve el aletlerini kullanırken güvenlik aksamlarını çıkarmamalı,

$\checkmark$ Kendilerine temin edilen kişisel koruyucu donanımları doğru kullanmalı ve korumalıdır.

$\checkmark$ Çalışma ortamında, işin yürütümü sırasında kendilerini tehlikeye sokacak çeşitli durumlar ile karşılaşmaları durumda, bir eksik görmeleri halinde işverene veya çalışan temsilcisine haber vermelidir.

$\checkmark$ İşveren tarafındav verile İş sağlığı ve güvenliği eğitimlerindeki kurallara uymalı, işletmeye zarar verici eylemlerden sakınmalidir. $\checkmark$ İşveren ve çalışan temsilci ile beraber müşterek çalışmaya özen göstermelidir.

İş sağlığ1 ve güvenliği kültürünün oluşması ve insanlarda İSG bilincinin oluşumunda üniversitelerin rolü büyüktür. İş kazalarına ve meslek hastalıklarına yol açan tehlike ve risklerin analiz edilmesinde yeni yöntemler geliştirmesi, yeni yöntem ve medotların oluşumunda sahip olduğu akademsiyenleri sayesinde rol model olmaktadır. İş sağlığı ve güvenliği alanında kalifiye insanların yetişmesinde, konferans ve kongrelerle İSG yi anlatarak çalışanlar üzerinde farkındalık oluşturmaktadırlar Tehlike ve risklerin analiz edilerek iş kazası ve meslek hastalıklarının önlenmesinde şekil 1'deki bilimsel yöntem integrasyonu önemli yer teşkil etmektedir(Şensögüut, 2018).

Şekil 1: Tehlike analizinin bilimsel yöntem ile integrasyonu(Şensöğ̈̈t, 2018).

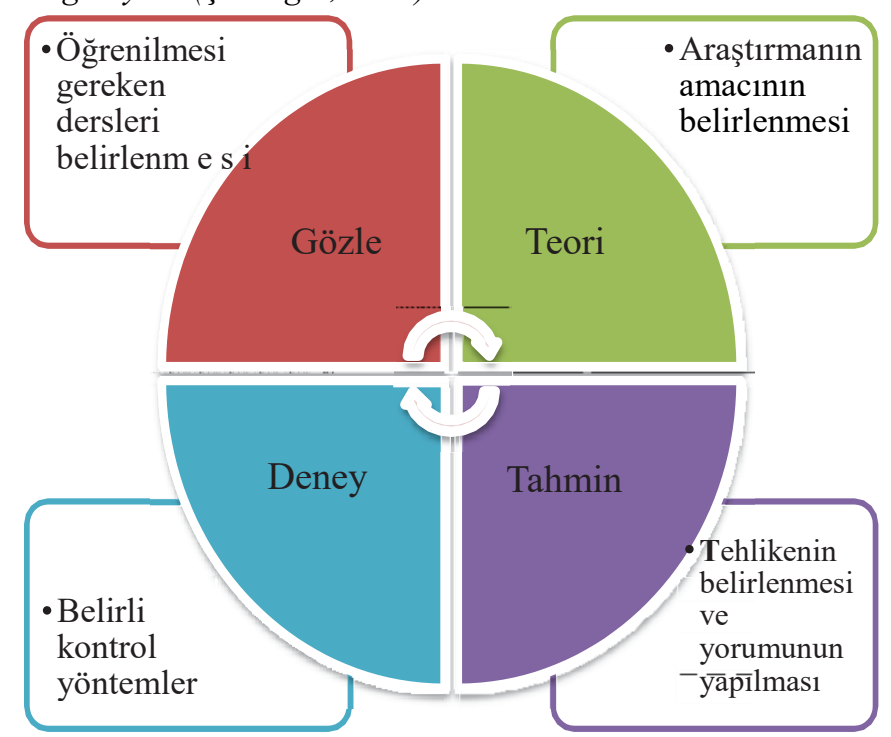

Ünivesiteler sahip oldukları araştırmacı kadrosu ve altyapısı ile çalışma ortamındaki tehlikeleri bilimsel yollar ile kaynağında kontrol ederek koruyucu yaklaşımlar geliştirmesini sağlayacak kurumlardır (Şensöğüt, 2018; Gür \& Yavuz, 2020).

\section{Materyal ve Metot}

\subsection{Araştırmanın Amacı}

Çalışmanın amacı; Hitit Üniversitesi’nde bulunan fakülte ve meslek yüksekokullarında 6331 sayılı İş Sağlığı ve Güvenliği Kanun'un işveren, işveren temsilcisi veya çalışan temsilcisi tarafindan uygulanmasının değerlendirilmesidir. Toplanan veriler çalışmanın amacı doğrultusunda analiz edilmiş ve değerlendirilmiştir.

\subsubsection{Araştırmanın Deseni}

Çalışmanın örneklemi 2 fakülte ve 2 meslek yüksekokulunda işveren, işveren temsilcisi ve çalışan temsilcileri görevlerinde bulunan kişilerdir. Çalışmada örneklem sayısının az olmasından dolayı veriler, görüşme yönteminin temel alındığı nitel araştırma yöntemlerinden olgu bilim deseniyle yapılmıştır. Bu yöntemle işveren, işveren temsilcisi veya çalışan temsilcilerinin İSG kanun kapsamında yükümlülüklerini ne kadar bildikleri ve bu yükümlülükleri yerine getirme durumları belirlenmeye çalışıldı.

\subsubsection{Katılımcılar}


Araştırmanın evrenini Hitit Üniversitesi'nde bulunan fakülte ve meslek yüksekokullarındaki işveren, işveren temsilcisi ve çalışan temsilcileri oluşturmaktadır. Çalışmanın örneklemi ise; 2 fakülte ve 2 meslek yüksekokulunda işveren, işveren temsilcisi ve çalışan temsilcileri oluşturmaktadır. Çalışmaya katılmayı kabul eden sekiz işveren, işveren temsilcisi veya çalışan temsilcisiyle yarı yapılandırılmış görüşme yapılmıştır. $\mathrm{Bu}$ çalışmaya katılanlardan biri kadın, yedisi erkektir. Çalışmaya katılan kadın işveren temsilcisi $\mathrm{K} 1$; erkek işveren, işveren temsilcisi veya çalışan temsilcileri E1, E2, E3, E4, E5, E6, E7 olarak kodlanmış ve isimler verilmemiştir. Çalışmaya katılan demografik özellikleri tablo 1'de verilmiştir.

Tablo 1: Demografik özellikler

\begin{tabular}{|c|c|c|c|c|c|c|c|c|}
\hline Çalıșan & $\mathbf{1}$ & $\mathbf{2}$ & $\mathbf{3}$ & $\mathbf{4}$ & $\mathbf{5}$ & $\mathbf{6}$ & $\mathbf{7}$ & $\mathbf{8}$ \\
\hline Yaș & 35 & 34 & 47 & 53 & 36 & 30 & 43 & 49 \\
\hline Ĕ̈itim durumu & Yüksek lisans & Yüksek lisans & Doktora & Lisans & Doktora & Lisans & Lisans & Lisans \\
\hline Çalıșma süresi (yıl) & 1 & 1 & 1 & 11 & 5 & 1 & 17 & 20 \\
\hline Cinsiyet & Kadın & Erkek & Erkek & Erkek & Erkek & Erkek & Erkek & Erkek \\
\hline Medeni durum & Evli & Evli & Evli & Evli & Evli & Evli & Evli & Evli \\
\hline Çalışılan birim & MYO & MYO & MYO & MYO & Fakülte & MYO & Fakülte & Fakülte \\
\hline
\end{tabular}

\subsubsection{Veri Toplama Aracı}

Çalışmaya başlamadan önce Hitit Üniversitesi'nde fakülte ve meslek yüksekokulunda iş sağlığı ve güvenliği çalışmaları gözlemlenerek notlar alınmıştır. Gözlemler sonucunda alınan notlar doğrultusunda İSG Kanun'unda işveren yükümlülükleriyle ilgili konular belirlenerek, odak grup görüşme soruları belirlenmiştir. Çalışma yapılmadan önce Hitit Üniversitesi rektörlüğünden çalışmanın uygulanması için izin alınmıştır. Örneklemdeki kişilerle görüşmeden önce kişilere çalışma konusunda ve amacında bilgi verildi. Böylece sorulara kendilerini rahat hissederek objektif cevap vermeleri sağlanmıştır. Görüşmeye başlamadan önce sorulara verilen cevapların olduğu gibi aktarılması ve eksikliklerin olmaması için görüşmenin ses kaydının yapılması gerektiği ifade edilmiştir. Ses kaydının alınması için kişilerden sözlü olarak izin alınmıştır. Kayıt altına alınan cevaplar değiştirilmeden yazıya dönüştürülmüştür. Görüşmeler ortalama 35-45 dakika arasında olmuştur.

\subsubsection{Veri Analizi}

Hitit Üniversitesi'nde fakülte ve meslek yüksekokulunda 6331 sayılı iş sağlığı ve kanunu kapsamında işveren, işveren temsilcisi veya çalışan temsilcisi olarak çalışanların yükümlülükleri hakkındaki bilgilerini tespit etmek için yapılan odak görüşme sonucu toplanan veriler analiz edilmiştir. Yazıya aktarılan veriler konuya bağlı olarak kategori listeleri halinde verilerek okuyucuya daha anlamlı hale gelmesi sağlanmıştır.

\subsubsection{Araştırmanın Etik Boyutu}

$\mathrm{Bu}$ çalışmaya başlamadan önce, Hitit Üniversitesi Girişimsel Olmayan Klinik Araştırmalar Etik Kurulu'ndan 2020-78 şaşvuru numarası ile 30. 04. 2021 taoplantı tarihli 2021-66 say1l karar numaras1 ile etik izni ve 12.01.2021 tarihli ve E-1014-900-2100001452 sayılı yazı ile Hitit Üniversitesi Rektörlüğünden izin alınarak çalışmaya başlanmıştır.

\section{Bulgular}

Yapılan odak grup görüşmesinde verilen cevaplar gözden geçirilerek aşağıdaki soru başlıkları oluşturulmuştur.

\section{S1: Biriminizde çalışan sayısı kaçtır?}

Aynı kurumda görev yapan K1 kişisi "62 akademik ve 9 idari personelimiz" bulunmaktadır derken E2 kişisi "60 akademik ve 10 idari personelimiz var. Bunların bir kısmının kadrosu bu birimde olmasina rağmen başka birimlerde görev yapan akademisyenlerimizde vardır" cevabını vermiştir.

E3 kişisi kendi biriminde "32 akademik, 8 idari, 4 temizlik ve 5 güvenlik görevlisi” cevabını verirken E5 kişisi "32 akademik, 18 idari personel olmak üzere toplam 50 personelimiz vardır" demiştir.

Farklı birimlerde görev yapan E4 kişisi "85 akademik ve 16 idari personel”, E6 kişisi "200'e yakın personelimiz var. Bunlardan 180 kişi akademik, 20 kişi idari personeldir. Üniversitede en fazla personele sahip birimiz", E7 kişisi "80 akademik ve 40 idari olmak üzere toplam 120 çalışanımız vardır" cevabını verirken E1 kişisi ise "18 ögrretim elemanı ve 3 idari personelimiz vardır” cevabını vermiştir.

S2: Biriminizde iş güvenliği uzmanı, iş yeri hekimi, İSG kurulu ve çalışan temsilcisi var mı? Bu görevlerdeki kişilerin kim olduğunu biliyor musunuz?

$\mathrm{K} 1$ kişisi "İş güvenliği uzmanımız var. İsmi ......., iş yeri hekimi ve çallşan temsilcilerinin kim olduğunu bilmiyorum. ISG kurulumuz var burada görevli kişiler olduğunu biliyorum ama tam olarak kimler var şu an hatırlamıyorum” cevabını, E2 kişisi "iş güvenliği uzmanımız var, iş yeri hekimimiz bulunmamaktadır. Çalışan temsilcisi olarak görevlendirdiğimiz kimse yok. Birimimizde çalışan temsilcisine çokta ihtiyaç yok, çalışanlar bir problemde direk bizimle iletişime geçebiliyorlar" cevabını vermiştir. E1 kişisi "Birimimizde iş güvenliği uzmanı, işyeri hekimi, ISG kurulu ve çalışan temsilcisi yok” cevabını, E4 kişisi ise "Işs güvenliği uzmanımız var, ismi....... İş yeri hekimimiz yok. Çalışan temsilcisi olarak ben görev yapıyorum, ISG kurulumuzda var ve her 3 ayda bir düzenli olarak toplanmaktadır." ifadesini kullandi.

S3: Biriminiz İSG kapsamında hangi tehlikeli sınıfta yer almaktadır? Biriminizin ISG Kanun kapsamında olması ve öğrencilerin bu kapsam dışında yer almasıyla ilgili görüşleriniz nelerdir?

E1 kişisi "Fabrikalara kıyasla birimimizin az tehlikeli sınıfta yer aldığını düşünüyorum. Ofis ortamında bile 8 saat oturarak 
çalışmak kişilerde ergonomik açıdan meslek hastalı̆̆ına sebep olabilir. Bu yüzden ISG koruyucu să̆llk hizmetlerini de içinde bulunduğundan ISG Kanun kapsamında birimimizin de yer alması doğrudur. Öğrenciler yasalara dahil edilmese de $\dot{I} S G$ dersini vererek onları bilinçlendirme yoluna gidiyoruz" derken, E4 kişisi "Birimimiz az tehlike sinıfinda yer almaktadır. Az tehlikeli sinffta yer alsak da yine de bir risk her zaman var. Riske karşı önlemlerde ancak yasalarla să̆landı̆̆ından kanun kapsamında olmamı doğrudur. Öğrencilerin ise kanun kapsamının dışında olması bence doğru. Öğrenci potansiyelinin fazla olduğu bu tür birimlerde öğrencilerin kanun kapsamına alınması bizim iş yükümüzü çok artırır" cevabını verirken E6 kişisi ise "Birimimiz az tehlikeli sınıfta yer alıyor. Sağllk hizmetleri devlet hastanesinde gerçekleşiyor, bu binada sadece idari işler yürütüldüğ̈̈nden az tehlikeli sinıfta yer sayllması doğrudur. Bizim birimimizde ögrenciler să̆llk sektöründe ögrenim gördüğünden kanun kapsamında yer alması gerekir", cevabını vermiştir.

S4: Biriminizde en tehlikeli alanlar nereleridir? Biriminizin risk değerlendirilme analizi var $\mathrm{m} 1$ ?

E2 kişisi "Burada en tehlikeli alan teras katı, elektrik hatlarının olduğu bölgelerdir. Atölyelerde de yüksek enerjili elektrikle çalışan kısımlar olduğundan potansiyel tehlike içerir. Ancak kurallara dikkat edilirse sikınt olmaz. Risk değerlendirme analizinin olup olmadı̆̆ını bilmiyorum ama gündemimizde sorunlu yerler var. Birkaç birimle ortak kullandı̆̆ımız alanlar var, buralarda çalışan birden fazla ISG uzmanı olması uygun değil" cevabını verirken, E3 kişisi "En tehlikeli alanımız bahçemiz. Çapa makinasından eli ya da parmağı kopan vaka olabilir. Bunun içinde personele işe uygun eğitim aldırdık. Risk değerlendirilmesi belirli periyotlarda yapılmaktadır. En son bir ay önce revizesi yapıldı" ifadesini kullanmıştır.

E7 kişisi "Kazan dairesi en tehlikeli alanımızdır. Birde yemekhane en alt katta olduğundan herhangi bir patlama veya yangından üst katlarda etkilenebilir. Bu da tehlike oluşturabilir. Risk değerlendirilmesi yapıld v ve belirli periyotlarla tekrar yapılmakta ve dokümanları mevcut" cevabını verirken, E6 kişisi ise "Tehlikeli alanımız yok. Risk değerlendirme analizi yapıldı̆̆ını hatırlıyorum ama hangi yılda yapıldı̆̆ını hatırlayamadım" cevabını vermiştir.

S5: Çalışanlarınızın işe giriş raporu var mı? Çalışanlarınıza İSG eğitimi verildi mi?

K1 kişisi “2016 yılında yapılan 8 saatlik bir ISG eğitimi yapıldı. Daha sonra verilen bir eğitim hatırlamıyorum. Göreve yeni başlayan personelden alınıp alınmadığını ve bu konuda yasal zorunluluk var mı bilmiyorum" cevabını verirken, E5 kişisi "Çalışanların săglı raporu olup olmadı̆̆ını hatırlamıyorum. Ama alınması gerektiğine inanıyorum. ISG ĕgitimi yeni başlayanlara veriliyor. Diğer personellere eğitim verilip verilmediğinden haberim yok" cevabını vermiştir.

E7 kişisi “iSG kapsamında bugüne kadar çalışanlara iki eğitim verildi. Çalışanlar işe başlarken onlardan sağlık raporu almıyoruz. Bence alınması gerek. Çalışanların hangi sağlık sorunları olduğunu bilsek hem onlara uygun görevler veririz hem de çalıştıkları alanlarda hastalıklarına karşı tehlike oluşturacak unsurlara tedbir alırız” cevabını verirken, E6 kişisi "Çalışanlardan sağllk raporu istiyoruz. Tip fakültesi olarak özellikle asistanlardan istiyoruz. İşe girişlerde sağlık raporunun alınması gerekli bence. ISG eğitimi çalışanlara bir kez verildi. $O$ eğitimden sonra eğitim verilmedi" cevabını vermiştir.
S6: Acil durumlarda görev yapacak personeliniz belirlendi mi? Bu kişilere görevleriyle ilgili eğitimler aldırıldı mı?

E6 kişisi "Acil durumlarla ilgili personeller belirlendi. Ama sadece ilk yardım ekibinin ĕgitimi var diğerlerinin yok”, E4 kişisi

"Acil durum ekiplerimiz üç yıl önce belirlendi ve çallşanlara duyurulmuştu. Sonra acil durumlarla ilgili bir şey yapılmadı" cevabını vermiştir. E2 kişisi "Arama kurtarma ekibi idari personelden seçildi, kimlerin seçildiğini bilmiyorum. Bu kişilere de herhangi bir eğitim verilmedi" ifadesini kullanırken, E5 kişisi ise "Acil durum ekiplerinden birisinde görevliydim. Ama şu an bu ekiplerde görevli kişiler kim bilmiyorum” cevabını vermiştir.

S7: Bugüne kadar biriminizde iş kazası veya meslek hastalığı yaşandı $\mathrm{m} ı$ ?

$\mathrm{K} 1, \mathrm{E} 1, \mathrm{E} 2, \mathrm{E} 4, \mathrm{E} 5, \mathrm{E} 6$ ve E7 kişisi birimlerinde iş kazası veya meslek hastalığı yaşanmadığını ifade ederken E3 kişisi "Bir iş kazası yaşadık. Çalışan elinden yaralanmıştı. Olaydan sonra bakanlı̆̆a bildirim yapmadı̆̆ımı için para cezası aldık. Bu konuda hastane haricinde bizimde bir bildirim yapmamı gerektiğini bilmiyorduk" cevabını vermiştir.

S8: ISG uygulamalarının biriminizde daha iyi uygulanabilmesi için ne yapılmalıdır? ISG Kanununda size verilen görevleri veya yükümlülükleri yerine getirirken zorluk yaşadınız mı?

E7 kişisi "Kanunda yer alan sorumlulukları yerine getirirken kısmen zorluk yaşıyorum. Bazen sorunlara çözüm bulamadı̆̆ımız süreçler yaşayabiliyoruz. Çalışanlar tarafindan tam anlaşılmadı̆̆ ve benimsenmediği için ISG uygulamaları tam olarak yapılamıyor. Bu yüzden ISG iyi anlatılmall, farkındalık oluşturularak herkes tarafindan benimsenmesi sağlanmalıdır”, E5 kişisi "Kanunun bize yüklediği yükümlülükleri yerine getirirken zorluk çekiyorum. Bu zorluğun tek sebebi maddi durumdan kaynaklaniyor. ISG uygulamalarının daha iyi uygulanması için kişilerin bilinçlendirilmesi lazım. Bunun için kişiye eğitim verilmeli ve uygulamaya geçilmelidir" cevaplarını vermişlerdir.

K1 kişisi “Kanunda bizim yükümlülüğümüzdeki işleri yaparken zorluk çektiğimiz durumlarda üst idareyi devreye sokarak işleri halletmeye çalışlyoruz. ISG'nin daha iyi uygulanabilmesi için farkındalık eğitimleri gerekli. Genel ISG konuları yerine spesifik konulara girilerek farkındalık yaratılmalıdır", E6 kişisi ise "kanun kapsamında yükümlülüklerimizi yerine getirirken zorluk çekmiyorum. Tüm birimlerde ISG uygulamalarının rutin hale getirilmesi, periyodik toplantı ve eğitimleri yapılması ISG uygulamalarını daha uygulanabilir hale getirmektedir" cevabını vermiştir.

\section{Sonuç}

Yapılan çalışmada üniversitenin farklı birimlerinde işveren, işveren temsilcisi ve çalışan temsilcisi görevlerinde bulunan kişilerin sorulara verdikleri cevaplar yorumlanmıştır. Çalışan sayılarının sorulduğu soruya verilen cevapların kesin değil yaklaşık sayılarla ifade edildiği gözlemlenmiştir. Özellikle birim yöneticilerin yasalar karşısında sorumlu olduğu kişi sayısını tam bilmemeleri dikkat çekicidir. 6331 sayılı ISG Kanunu'nda çalışan temsilcisi, yıllık eğitim sürelerinin belirlenmesi, acil durum vb. planlarının tam ve eksiksiz yapılabilmesi için çalışan sayısının net bilinmesi gerekir. İşveren, işveren temsilcisi ve çalışan 
temsilcilerinin bir an önce net personel sayılarını güncellemesi ve bu konuda bilgi sahibi olmalıdir.

Görüşmeye katılanlardan biri hariç diğer kişiler birimlerinde iş güvenliği uzmanının görev yaptığını, İSG kurulunun varlığından haberdar olduklarının fakat kurulda görevli kişileri kim olduğunu bilmediklerini ve işyeri hekiminin görev yapmadığını ifade etmişlerdir. Bir birimde henüz İSG faaliyetlerine hiç başlanılmamış olması burada çalışanların iş kazası ve meslek hastalığı potansiyelinin daha fazla olduğu anlamına gelmektedir. Yönetimin, iş güvenliği uzmanını tanımaları İSG kâtip üzerinden sözleşme yapmalarından veya mevcut risklerle ilgili çalışmaların yapılmasından olabilir. Ancak İSG kurulunda kimlerin olduğunun bilinmemesi az tehlikeli sınıfta yer alan birimlerde üç ayda bir kurulun toplanması gerekliliğinin tam manasıyla yapılmadığının göstergesidir. Birimlerdeki İSG çalışmalarında kuruldaki kişilerle takım çalışması ve beyin firtınası yapılarak alınacak önlemler belirlenmeli ve uygulanmalıdır. Bu şekilde ancak kurulda alınan kararların daha çok benimsenmesi sağlanacaktır. İSG çalışmalarının kâğıt üzerinde değil özümsenerek yapılması en önemli şarttır.

Çalışmaya katılanların tamamı birimlerinin az tehlikeli sınıfta yer aldığını ifade etmişlerdir. Ofis çalışanlarının çoğunlukta olduğu kamu kurumları İSG kapsamında az tehlikeli sınıfta yer almaktadır. İşveren, işveren temsilcisi ve çalışan temsilcisinin birimlerinin tehlike sınıflarını bilmeleri buna göre yükümlülüklerini yerine getirme açısından oldukça önemlidir. Öğrencilerin ISG kanun kapsamına dâhil edilmesi sorusuna genellikle olumlu görüşler beyan edilmiştir. Bunun temel nedeni yasalarda her ne kadar kapsam dışı bırakılmasına rağmen onların birim içerisinde yaşayacağı bir iş kazasından sorumlu olacağının ifade edilmesidir. Yasaya dâhil edilmemesini isteyenler ise sorumlu olunan kişi sayısının artmasının kendileri için daha zorlu bir süreç yaratacağını düşünmektedirler. İSG de bireylerin sağlığ tüm yapılan işlerden önemlidir. Bunun için birim içerisinde en aktif ve en çok sayıya sahip olan öğrencilerinde ISG Kanun kapsamına dâhil edilmesi önemli bir adım olacaktır. Öğrencilerin kanun kapsamına alınması onlara İSG eğitimlerinin verilmesi, birim içerisindeki risklerden ve alınacak tedbirlerden haberdar edilmesi, uygulamalı bölümlerde öğrencilere KKD sağlanması açısından önemlidir.

Odak grup görüşmesine katılanlar birim risk değerlendirme analizlerinin yapıldığını ifade etmelerine rağmen risk analizinin hangi tarihte yapıldığı hakkında bilgileri bulunmamaktadır. $\mathrm{Bu}$ cevaplar 6331 sayılı ISG kanun kapsamında yükümlülüklerin tam olarak bilinmediği, sürecin tam olarak yöneticiler tarafindan takip edilmediğinin bir kanıtıdır. Bu yüzden öncelikle yöneticilere İSG kanunundaki yükümlülükleri ve yerine getirilmeyen yükümlülükler sonucu karşılaşacakları idari ve para cezaları anlatılarak farkındalık düzeyleri artırılmalıdır. Yöneticilere biriminizdeki en tehlikeli alanlarınız ne dendiğinde kendi düşüncelerine göre teras, bahçe, yemekhane gibi yerleri ifade ettiler. Oysaki risk değerlendirme analizini iş güvenliği uzmanı ve iş sağlığı ve güvenliği kuruluyla birlikte yapsalar veya gelişen duruma göre risk analiz revize çalışmalarına katılsalard 1 bu cevapların çoğuyla karşı karşıya kalmazdık. Risk değerlendirme analiz sonuçlarındaki skorlara bağlı acil ele alınması gereken kısımlar zaten bellidir. Yöneticilerinde bu risk değerlendirme analizlerini özümsemeleri ve birimlerin risklerinden haberdar olması gerekmektedir.

Yöneticilerin çalışanların İSG eğitimi almalarıyla ilgili soruya genellikle evet cevabı verilirken, eğitimin hangi yılda kaç saat ve kaç kişiye eğitim verildiği tam olarak bilinmemektedir. İG Kanununda az tehlikeli sınıfta yer alan işyerlerinde çalışanlara 3 yılda bir en az 8 saatlik belirlenen konularda eğitim verilmesi gerekmektedir. $\mathrm{Bu}$ yüzden birim yöneticilerin bir an önce eğitimlerdeki eksiklikleri tamamlamaları gerekmektedir. Verilen eğitimlerle çalışanların İSG farkındalıkları artırılarak kişisel hatalardan kaynaklı iş kazası ve meslek hastalıkları sayısının en aza indirmek hedeflenmelidir.

İşverenler, işveren vekilleri ve çalışan temsilcileri birimlerinde acil durum ekiplerinin oluşturulduğunu söylerken, ekipte görev yapanları bilmediklerini ifade etmişlerdir. Acil durumlarda (yangın, sel, patlama, deprem vb.) birimlerdeki çalışanların olaylardan en az etkilenmelerini sağlayacak şekilde ekiplerin kurulması oldukça önem arz etmektedir. Ekiplerde bulunan kişilerin tüm çalışanlar tarından bilinmesi acil durumlarda kiminle iletişime geçileceği ve müdahalenin kim tarafından yapılacağının bilinmesi açısından önemlidir. İşveren tarafindan acil durum ekiplerinde görev yapanların görevleriyle ilgili yetkili kuruluşlardan eğitim alması sağlanmalıdır. Doğru yapılan her müdahalenin hayat kurtardığı, yanlış ve eksik yapılan müdahalenin ise sakatlık ve ölümle sonuçlanacağ 1 unutulmamalidir.

Çalışmaya örneklem olan birimlerden sadece birinde küçük yaralanmayla sonuçlanan bir iş kazası yaşanmıştır. Ancak iş kazası bildirimi yapılmadığı için para cezası aldıklarını ifade etmişlerdir. Bunun sebebi işverenlerin ve yöneticilerin İSG kanunu kapsamındaki kendi yükümlülüklerini bilmemeleridir. Çalışan eğitimlerine mutlaka yöneticilerinde katılımı sağlanmalı ve ISG profesyonelleri tarafindan işveren ve çalışan yükümlülükleri detaylı anlatılmalıdır. Yöneticiler kendi sorumluluklarını bilip, uygular ve çalışana uygulatırsa ISG Kanunu tam anlamıyla kamu kurumlarında da hayata geçmiş olacaktır.

\section{Teşekkür}

$\mathrm{Bu}$ iş sağlığı ve güvenliği çalışmasının birimlerde yapılmasında gereklivdesteği esirgemeyen Hitit Üniversitesi Rektörü Prof. Dr. Ali Osman ÖZTÜRK'e ve birimlerdeki ilgili yöneticilere teşekkür ederiz.

\section{Kaynakça}

Terzioğlu, A. \& Aksungur, A. (2019). İş sağlığı ve Güvenliğinde İşverenin Hukuki ve Cezai Sorumluluğu. Dicle Üniversitesi Adalet Meslek Yüksekokulu Dicle Adalet Dergisi, 3 (6), 1254.

Aktan, C. C. \& Işı, A. (2007). 21. Yüzyılda Herkes İçin Sağlık: 21 Hedef. İstanbul:Aura Yayınları.

Hekimler, A. (2012). 4857 Sayılı İş Kanunu'nda Düzenleme Bulmuş Olan İş Sağlığı ve Güvenliğine İlişkin İşverenlerin 
Temel Yükümlülükleri. Tekirdă̆ S.M.M.M. Odası Sosyal Bilimler Dergisi. Sayı 1, s. 5.

Bayram, F. (2005). Yeni İş Sağlığı ve Güvenliği Mevzuatımıza Hâkim Olan İlkeler. Legal İs Hukuku ve Sosyal Güvenlik Hukuku Dergisi, Sayı 7, s. 1104, ss:2-3.

Çakan, M. \& Yavuz, Ş. (2020). Üniversitelerdeki İş Să̆lı̆̆l ve Güvenliği Konusundaki Risk Faktörlerinin Önem Derecelerine Göre Siralanması: Hitit Üniversitesi Örneği. Elçin YAZICI (Ed.), Eğitim Araştırmaları-2, 1-24, 2. Baskı, Ankara: İKSAD Uluslararası Yayınevi.

Çiçek, Ö. \& Öçal, M. (2016). Dünyada ve Türkiye'de İş Sağlığı ve Güvenliğinin Tarihsel Gelişimi. Uluslararası Emek ve Toplum Dergisi. Cilt 5 Sayı 11, s. 109.

Kabakçı, M. (2009). İş Sağlığı ve Güvenliğinin Hukuk Sistemindeki Yeri. Türkiye Barolar Birliği Dergisi, Sayı 86, s. 250 .

Şen, M. (2015). İş Sağlığı ve Güvenliği Kavramı, Tarihsel Gelişimi ve Dayanakları. MÜHFD, Cilt 4 Sayı 1, s. 130.

Süzek, S. (2012). Işs Hukuku. Ankara: Beta Yayınevi, s. 905.

Aytekin, Ş. (2012). İş Sağlığı ve Güvenliği Kanun Tasarısı Taslağında Dünden Bugüne. Sicil İş Hukuku Dergisi. Cilt 7, Say1 25, ss. 93-105.

Cengiz, İ. (2018). İşverenin İş Kazasından Doğan Hukuki Sorumluluğu. Türkiye Adalet Akademisi Dergisi, (34), 123142.

6331 sayılı İş Sağlığı ve Güvenliği Kanunu. İş Kazası, Sayı: 28339, Yayınlanma Tarihi: 30 Haziran 2012

Güzel, A., Okur, A.R. \& Caniklioğlu, N. (2016). Sosyal Güvenlik Hukuku. İstanbul: Beta Basım Yayım Dağıtım.

Tuncay, A. C., \& Ekmekçi, Ö. (2016). Sosyal Güvenlik Hukuku Dersleri. İstanbul: Beta Basım Yayım.

Yılmaz, A. (2017). Sosyal Güvenlik Hukukunda İş Kazası Kavrami: Kita Avrupası ve Anglosakson Hukuk İstemlerinden Birer Örnek ile Türk Hukuku Karşılaştırması. Sosyal Güvence, 0 (11), 107-127.

The Fabian Society (1901). The Workman's Compensation Act 1897, What It Means, and How to Make Use of It: The Fabian Society.http://digital.library.lse.ac.uk/objects/lse:rax644kib/r ead/single\#page/4/mode/2up adresinden ulaşılmıştır.

Sosyal Sigortalar ve Genel Sağlık Sigortası Kanunu (16.06.2006). No 5510, Resmî Gazete, 26200, 5, C: 45.

Ilıman, E. (2015). Türkiye'de Meslek Hastalıkları. Uluslararası Sağlık Yönetimi ve Stratejileri Araştırma Dergisi, 1 (1), 21 36.

Boz Eravc1, D. (2019). 6331 Sayılı İş Sağlığı ve Güvenliği Kanunu ve İlgili Yönetmelikleri Çerçevesinde İşverenin Yükümlülükleri. Hak İş Uluslararası Emek ve Toplum Dergisi, 8 (22), 330-355. DOI: 10.31199/hakisderg.644319.

Kökten, M. \& Avinç, O. (2014). 6331 Sayılı İş Sağlığı ve Güvenliği Kanunu'nda İşveren Yükümlülükleri ve Tekstil Sektörü Açısından Bir Bakış. Tekstil ve Mühendis, 21 (93). DOI: 10.7216/130075992014219305.

Kurt, Resul \& Kurt, Dilek (2012). 6331 Sayılı İş Sağlığı ve Güvenliği Kanunu ile İşverenlere Getirilen Yükümlülükler ve
İdari Yaptırımlar. Mali Çözüm. 113 (2012/Eylül-Ekim): 217 234.

Üngüren, E \& Koç, T. (2015). İş Sağlığı ve Güvenliği Uygulamaları Performans Değerlendirme Ölçeği: Geçerlik ve Güvenirlik Çalışması. SGD-Sosyal Güvenlik Dergisi, 5 (2), 124-144.

Akpınar, T. \& Çakmakkaya, B. Y. (2014). İş sağlığı ve güvenliği açısından işverenlerin risk değerlendirme yükümlülüğü. Çalışma ve Toplum, 0(40), 273- 304.

Etöz, M \& Tulga, İ. (2015). İş Sağlığı ve Güvenliği Hizmetleri için Yeni Bir Model: Araç ve Hizmet Rotalama Problemi (AHRP) ve Ampirik Uygulamas1. Akdeniz IIIBF Dergisi, 15 (32), 53-65.

Erol, S. (2015). İş Sağlığı ve Güvenliği Konusunda İşveren, Çalışan ve Devletin Rolü. ASSAM Uluslararası Hakemli Dergi, 2 (4), 86-103.

Şensöğüt, C. (2018). İş Güvenliği Kültürü ve Üniversiteler. Soma Meslek Yüksekokulu Teknik Bilimler Dergisi, 1 (25), 9-15.

Gür, B. \&Yavuz, Ş.(2020). Üniversitelerin İş Sağlığı ve Güvenliği Programında Görev Yapan Akademisyenler Üzerine Bir İnceleme. ISPEC Journal of Social Sciences Humanities, 4(4), 328-342. 